\title{
PELATIHAN PEMBUATAN ALAT PERAGA IPA BAGI GURU SMP IT AL HIKMAH
}

1) Drs. Abdullah Mas'ud, M.T. 2). Drs. Mudjiono,M.Pd. 3) Drs. Aly Imron,M.Pd. Program Studi Teknik Listrik, Jurusan Teknik Elektro, Politeknik Negeri Malang

masud.polinema@yahoo.com

\begin{abstract}
Abstrak - Permasalahan yang dihadapi guru-guru SMP IT AL HIKMAH adalah terbatasnya dana dan tersedianya alat peraga pada proses pembelajaran IPA. Demikian juga minimnya pengetahuan, pengalaman dan ketrampilan dalam penggunaan dan pembuatan alat peraga IPA yang akan digunakan untuk menyampaikan materi pembelajaran IPA pada siswa. Melalui pelatihan dan bimbingan teknis membuat alat peraga IPA dengan memanfaatkan barang yang murah atau barang yang tidak terpakai, kami menawarkan solusi guna meningkatkan kemampuan dan ketrampilan guru dengan memberi pelatihan dan bimbingan teknis yang meliputi: a). cara mengunduh materi pembelajaran IPA (Buku BSE, youtube,power point, animasi) dari internet. b) Memberi bimbingan teknis pembuatan alat peraga IPA. Desain penyampaian materi pelatihan dan bimbingan teknis dengan enggunakan metode, antara lain: a) Menyampaikan tujuan PKM, b) Mendemonstrasikan Keterampilan penggunaan alat peraga IPA, c) Pelatihan dan bimbingan teknis pembuatan alat peraga IPA dan sekaligus menyusun lembar kerja siswa, d) Mengecek dan umpan balik dari materi yang telah disampaikan dan e) diskusi Pelatihan lanjutan dan penerapan. Desain materi pelatihan dan bimbingan teknis di atas diharapkan dapat,meningkatkan pengetahuan, pengalaman, ketrampilan dan kemampuan guru pembuatan alat peraga IPA dan penyampaian materi kepada siswanya,
\end{abstract}

\section{Kata kunci: Alat peraga, SMP IT Al hikmah, PKM}

\section{PENDAHULUAN}

\subsection{Analisis Situasi}

Hasil observasi terhadap pembelajaran IPA di SMP IT AL HIKMAH, guru dituntut untuk menguasai berbagai bidang ilmu yang harus diajarkan kepada siswa dengan metode pembelajaran yang berbasis proyek.. Untuk itu perlu penerapan pembelajaran IPA yang dapat meningkatkan aktivitas dan hasil belajar siswa, yaitu dengan dengan menyertakan penerapan metode eksperimen/percobaan dan penggunaan media pembelajaran IPA. Oleh karena itu melalui pengabdian ini kami dari team PPM Politeknik Negeri Malang (Polinema) akan memberikan pelatihan pembuatan media pembelajaran berupa pembuatan alat peraga IPA khususnya fisika kepada para guru dan peserta didik dengan harapan bisa membuka cakrawala baru dalam proses belajar-mengajar. Dalam pengabdian ini, kegiatan lebih menekankan pada pelatihan yang konkrit sehingga para guru dan siswa tidak hanya mengetahui melalui buku, tetapi mengetahui melalui berbagai pengalaman yang mereka lakukan sendiri dengan membuat alat peraga sederhana.

\subsection{Permasalahan Mitra}

Pembelajaran IPA di SMP IT Al-Hikmah diarahkan terciptanya kondisi siswa agar tertarik dan termotivasi belajar untuk memecahkan masalah. Upaya peningkatan kualitas guru IPA SMP IT AlHikmah oleh pemerintah maupun yayasan sudah lama dilakukan melalui pelatihan ,seminar, workshop dan Lokakarya, namun masih banyak guru yang belum mendapat kesempatan yang memadahi dalam kegiatan ini. Selain itu permasalahan yang dihadapi guru SMP IT AL HIKMAH , antara lain ;

a. Terbatasnya media pembelajaran, alat peraga, sarana dan prasarana mengajar.

b. Kurang pengalaman dalam membuat dan memperagakan alat bantu IPA

c. Kurang menguasai penggunaan media pembelajaran dengan multimedia.

\section{TINJAUAN PUSTAKA}

\subsection{Pendekatan Alat Peraga IPA}

Pemilihan pendekatan alat peraga yang tepat untuk pokok bahasan tertentu ternyata membantu efektivitas pengajaran pokok bahasan yang bersangkutan (Lorber and Rierce: 1990:108). Pembelajaran IPA yang hanya bersifat tektual akan mengakibatkan: (1) timbulnya salah konsep pada siswa, (2) terjadinya pengetahuan hapalan, dan (3) terjadinya kemampuan semu pada siswa (Djohar,1999). Sejalan dengan itu perlu kiranya pembelajaran IPA dilengkapi dengan alat peraga dan metode pembelajaran yang memadai

\subsection{Metode Pembelajaran IPA di MI/SD}

Pelajaran IPA yang di dalamnya mencakup biologi dan fisika untuk siswa tingkat MI/SD sebenarnya tidak sulit. Hal ini disebabkan karena obyek yang dibahas dalam pelajaran tersebut ada di sekitar kita. Tinggal sekarang para guru mau atau tidak menggunakan lingkungan tempat kita hidup sebagai media pembelajaran. Pelajaran IPA bila diberikan dengan cara ceramah akan menjadi sangat sulit. Daya nalar anak tingkat sekolah dasar belum cukup untuk membayangkan dan merasionalisasikan cerita yang disampaikan guru. Para guru sebenarnya menyadari bahwa metode pembelajaran yang mereka gunakan tidak cocok namun para guru dibatasi oleh tugas lain sehingga tidak ada waktu untuk membuat persiapan menggunakan metode pembelajaran yang lebih 
berpusat pada siswa. Akibatnya hasil belajar siswapun cenderung hanya sebatas menghafal konsep yang diajarkan oleh guru, mereka tidak mempunyai keberanian melakukan inovasi dan rekonstruksi apa yang mereka terima dari guru. Kalau toh kemudian pada akhir semester mereka mendapatkan nilai yang baik bahkan sempurna (100) bukan berarti prestasi tersebut menunjukkan keberhasilan metode pembelajaran guru namun lebih pada tingkat hafalam mereka pada konsep..

\subsection{Pembelajaran IPA Kontekstual}

Proses pembelajaran IPA kontekstual yang dikaitkan dengan pengalaman anak dan kehidupannya sehari-hari dikembangkan untuk menarik minat anak belajar IPA secara nyata. Melibatkan siswa dalam proses Sains dapat dimulai dari pemanfaatan obyek atau fenomena nyata sehari-hari sebagai sumber belajar, misalnya Sepeda Motor, Kebun Sekolah, Pohon, dan lain lain.

Dalam rangka mengembangkan kegiatan Pembelajaran IPA kontekstual, siswa melakukan observasi, merumuskan hipotesis, melakukan eksperimen, menarik kesimpulan, membuat laporan, dan menerapkan etik untuk IPA. Semua kegiatan berorientasi pada keaktifan siswa, Siswa belajar IPA, ketika siswa melakukan ..

1. Observing (menggunakan semua indera)

2. Sorting and Grouping (membandingkan, mengelompokkan, melihat pola persamaan/ perbedaan anak)

3. Raising questions (bertanya)

4. Predicting (making hypotheses, membuat hipotesis )

5. Testing (eksplorasi, investigasi, memberi perlakuan),

6. Recording (merekam, mengumpulkan data, mengumpulkan informasi)

7. Interpreting findings (membuat grafik pengamatan, menganalisis hasil)

8. Communicating (melaporkan, mendiskusikan temuan dengan guru, mendiskusikan dengan teman, melaporkan hasil, memajang hasil temuan)

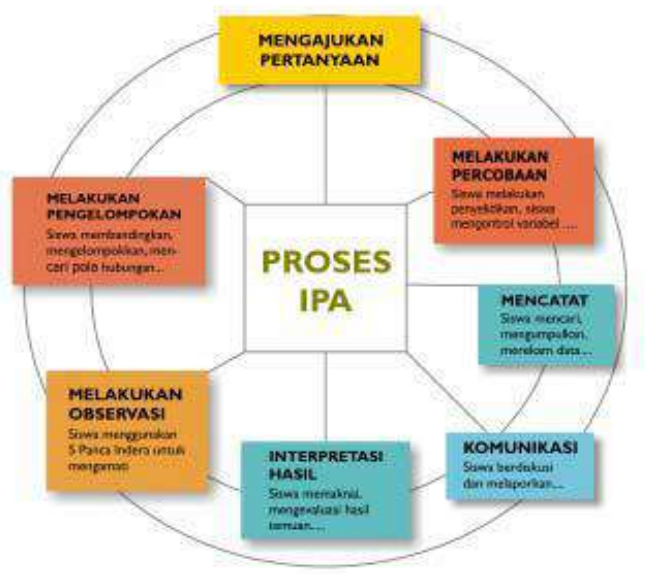

2.4 Pembelajaran IPA melalui Eksperimen a. Teropong Bintang
Teropong bintang digunakan untuk mengamati obyek-obyek yang ada di langit (bintang). Teropong bintang terdiri dari sebuah lensa cembung yang berfungsi sebagai lensa obyektif dengan diameter dan jarak fokus besar, sedangkan okulernya adalah sebuah lensa cembung dengan jarak fokus pendek.

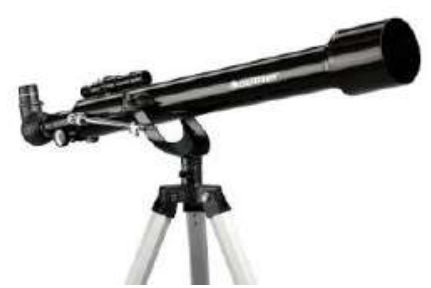

b. Tekanan dalam zat cair

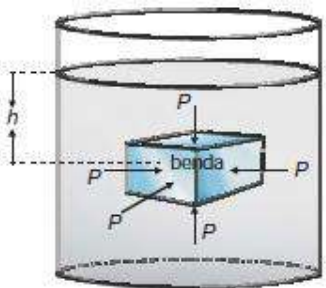

Gambar 2.2 Tekanan fluida pada benda

a) Zat cair menekan ke segala arah.

b) Semakin dalam letak suatu titik dari permukaan zat cair, tekanannya semakin besar.

c) Tekanan zat cair tidak tergantung pada bentuk wadahnya, melainkan tergantung pada kedalaman dari permukaan zat cair.

d) Tekanan zat cair bergantung pada massa jenis zat cair.

\section{c. Tekanan Hidrostatis}

Tekanan hidrostatis adalah tekanan dalam zat cair yang disebabkan oleh berat zat cair itu sendiri. Besarnya tekanan hidrostatis zat cair dipengaruhi beberapa faktor, yaitu kedalaman, massa jenis zat cair, dan percepatan gravitasi..

Keterangan:

$$
\mathbf{P}=\rho \cdot \mathbf{g} \cdot \mathbf{h}
$$

\section{d. Hukum Pascal}

Tekanan yang diberikan pada zat cair dalam ruang tertutup diteruskan ke segala arah dan sama besar"
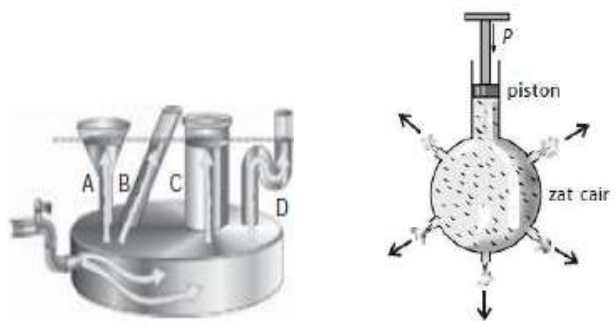

e. Roket Air 
Roket air adalah sebuah botol berisi air dan diberi tekanan udara yang tinggi didalamnya, jika tutup botol dibuka akan meluncur menghasilkan tenaga semburan yang besar.

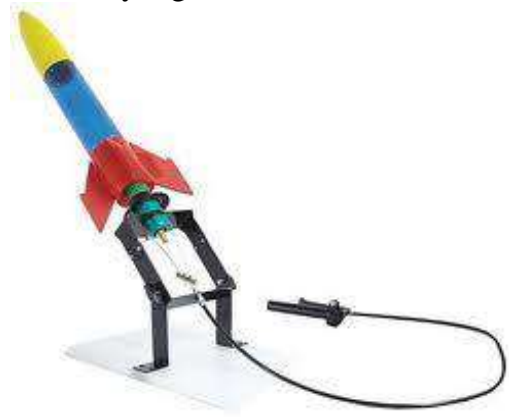

Prinsip kerjanya mengacu kepada hukum ketiga Newton dan kekekalan momentum. Air yang keluar dari botol memberi gaya yang besar untuk mendorongnya ke depan.

\section{f. Bejana Berhubungan}

Hukum bejana berhubungan berbunyi:"Bila bejanabejana berhubungan diisi dengan zat cair yang sama dan berada dalam keadaan setimbang maka permukaan zat cair dalam bejana bejana terletak pada sebuah bidang datar.

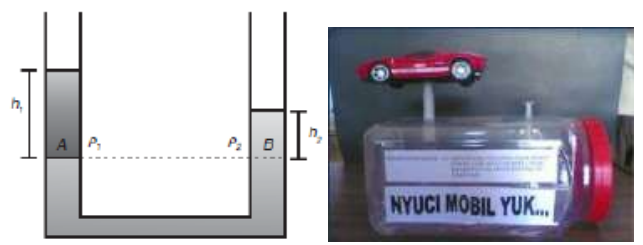

\section{g. Hukum Archimedes}

Suatu benda yang dicelupkan sebagian atau seluruhnya ke dalam zat cair akan mengalami gaya ke atas yang besarnya seberat zat cair yang dipindahkan oleh benda tersebut."

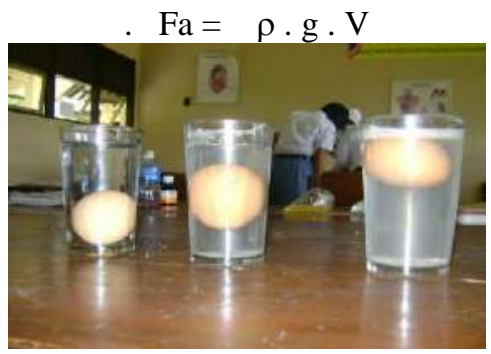

Dengan menggunakan konsep gaya Archimedes, kedudukan suatu benda dalam zat alir dibedakan menjadi 3, yaitu mengapung, melayang, dan tenggelam.

\section{Mengapung}

Suatu benda dikatakan mengapung jika besar gaya ke atas atau gaya Archimedesnya lebih besar dibanding gaya ke bawahnya (gaya beratnya).

2. Melayang

Suatu benda dikatakan melayang atau terbang jika besar gaya ke atas (gaya Archimedes) sama dengan gaya ke bawah (gaya berat) benda tersebut. Secara matematis dapat dituliskan sebagai berikut.

\section{Tenggelam}

Suatu benda dikatakan tenggelam jika besar gaya ke atas (gaya Archimedes) lebih kecil daripada gaya ke bawahnya (gaya beratnya).

\section{h. Hukum Kekekalan Momentum}

Jumlah momentum sebelum tumbukan sama

dengan jumlah momentum sesudah tumbukan.

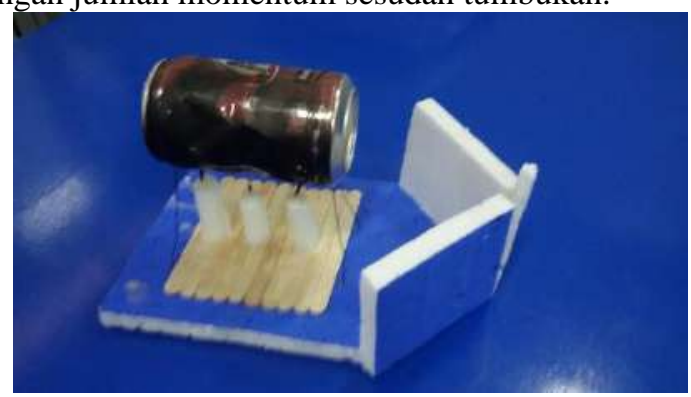

Alat Peraga Aplikasi Hukum Kekekalan momentum

\section{i. Hukum Faraday}

Gaya gerak listrik yang timbul pada kumparan yang berada dalam medan magnet berbanding lurus dengan perubahan medan magnet.

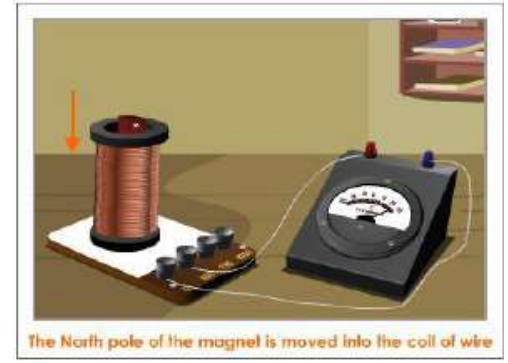

Alat Peraga Aplikasi Hukum Faraday

\section{TUJUAN DAN MANFAAT KEGIATAN}

\subsection{Tujuan Kegiatan}

a. Memberi bimbingan kepada guru SMP IT AL HIKMAH dalam pembuatan alat peraga IPA.

b. Bimbingan teknis kepada guru dalam merakit dan menggunakan alat peraga IPA

\subsection{Manfaat Kegiatan}

a. Sebagai dasar pengembangan dan peningkatan profesionalisme guru dalam menyajikan materi IPA melalui media/alat peraga.

b. Guru trampil dalam pembuatan alat peraga IPA bagian dari materi pelajaran IPA.

\section{MATERI DAN METODE}

\subsection{Khalayak Sasaran}

Khalayak sasaran adalah guru SMP IT AL HIKMAH. Dalam pelaksanaannya, team PPM bersama mitra atau partner kerja bekerja sama dalam pelaksanaan pelatihan dan bimbingan teknis membuat alat peraga IPA(adaptor) sebagai alat peraga IPA dan media pembelajaran IPA dan kemudian menyerahkan langsung hasil kerja kepada Sekolah partnernya. 
4.2 Metode Pengabdian Kepada Masyarakat Metode pelaksanaan yang dilakukan, antara lain;

a. Team dosen mengkonstruksikan solusi permasalahan melalui cara memotivasi, membimbing, memberi ilmu pengetahuan dan/atau teknologi,.

b. Team PPM Bersama guru SMP IT AL HIKMAH mengembangkan pengetahuan dengan mencari aplikasi IPA pada kehidupan sehari-hari .

Tabel 1. Model Pelaksanaan PKM

\begin{tabular}{|c|c|}
\hline $\begin{array}{c}\text { MODEL } \\
\text { PELAKSANAA } \\
\mathbf{N}\end{array}$ & $\begin{array}{c}\text { PERAN TEAM } \\
\text { PENGABDIAN MASYARAKAT }\end{array}$ \\
\hline $\begin{array}{l}\text { 1. Menyampaikan } \\
\text { tujuan }\end{array}$ & $\begin{array}{l}\text { menjelaskan tujuan dan } \\
\text { kompetensi yang ingin dicapai. }\end{array}$ \\
\hline $\begin{array}{l}\text { 2. Demonstrasi } \\
\text { keterampilan }\end{array}$ & $\begin{array}{l}\text { mendemonstrasikan keterampilan } \\
\text { atau menyajikan informasi tahap } \\
\text { demi tahap }\end{array}$ \\
\hline $\begin{array}{l}\text { 3. Pelatihan dan } \\
\text { bimbingan }\end{array}$ & $\begin{array}{l}\text { memberi pelatihan penggunaan } \\
\text { alat peraga IPA dan media } \\
\text { pembelajaran }\end{array}$ \\
\hline $\begin{array}{l}\text { 4. Mengecek dan } \\
\text { umpan balik }\end{array}$ & $\begin{array}{l}\text { Monev guru melakukan tugas } \\
\text { dengan baik, memberikan umpan } \\
\text { balik }\end{array}$ \\
\hline $\begin{array}{l}\text { 5. Pelatihan } \\
\text { lanjutan dan } \\
\text { penerapan }\end{array}$ & $\begin{array}{l}\text { mempersiapkan kesempatan } \\
\text { melakukan pelatihan lanjutan, } \\
\text { khusus pada penerapan kehidupan } \\
\text { sehari-hari }\end{array}$ \\
\hline
\end{tabular}

\subsection{Rancangan Evaluasi}

Evaluasi dilakukan pada akhir kegiatan dan hasilnya digunakan untuk memperbaiki kelemahan dan kekurangan hasil kegiatan. Untuk menguji efektivitas kegiatan pelatihan dan bimbingan teknis. Rancangan evaluasi kegiatan pengabdian ini meliputi tiga aspek,

a. Tingkat kelayakan terhadap materi ‘

b. Tingkat relevansi terhadap materi .

c. Tingkat kelayakan sekolah yang menjadi sasaran.

\section{HASIL DAN PEMBAHASAN}

\subsection{Pendahuluan}

Kegiatan PKM ini didukung oleh sumber daya manusia yang sesuai dengan bidangnya, serta sarana prasarana yang memadai untuk mendukung kegiatan pelatihan dalam rangka penerapan Ipteks. Sedangkan potensi yang dimiliki oleh para Guru-guru SMP IT AL HIKMAH adalah semangat, kemauan dan kemampuan untuk mendapatkan pelatihan dan pembinaan tentang pembuatan media pembelajaran dan penggunaan alat peraga IPA.

Melalui kegiatan ini, Polinema ikut berperan nyata dalam upaya meningkatkan kemampuan Guru-guru dalam pelatihan pembuatan alat peraga IPA

\subsection{Hasil Pelaksanaan Kegiatan PKM}

Hasil pelaksanaan kegiatan pengabdian pada masyarakat berupa transfer ilmu pengetahuan dan teknologi (Iptek), bahan yang diperlukan untuk membuat alat peraga IPA, alat peraga pendidikan IPA dan Lembar Kerja Siswa (LKS). Guru dilatih dan dibimbing membuat/membuat alat peraga IPA

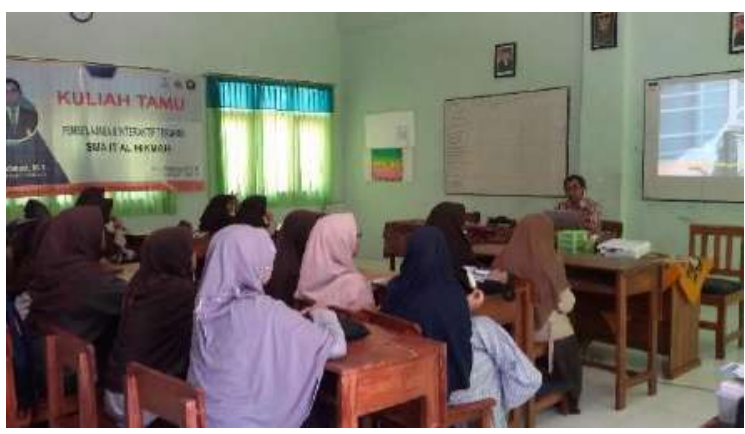

Peserta pembelajaran alat peraga IPA

\subsection{Permasalahan dalam proses Pembelajaran}

Permasalahan yang dihadapi guru-guru SMP IT AL HIKMAH adalah kurang terbiasa menggunakan dan membuat alat bantu media pembelajaran berupa alat peraga IPA sekaligus sebagai bahan untuk melakukan eksperiman/percobaan, oleh karena itu dipandang perlu para guru SMP IT AL HIKMAH untuk mendapat bimbingan teknis dalam pembuatan alat peraga IPA sebagai sarana untuk melakukan percobaan/eksperimen dalam rangka meningkatkan kualitas sumber daya guru dengan harapan bisa meningkatkan kualitas pembelajaran.

Dalam usaha membantu pemecahan masalah yang dilakukan oleh team P2M Polinema berupa pelatihan dan bimbingan teknis dalam rangka melaksanakan Tri Dharma Perguruan Tinggi. Pelatihan dilaksanakan dengan menggunakan metode ceramah dengan teknik tanya jawab, metode eksperimen kemudian dilanjutkan dengan melakukan percobaan dan simulasi.

Pelatihan dan bimbingan teknis ini dirancang dalam beberapa tahapan, antara lain;

a. Melakukan presentasi dengan menyampaikan penjelasan tentang konsep dasar IPA

b. Memberi pelatihan kepada guru SMP IT AL HIKMAH penggunaan alat peraga IPA untuk keperluan pengajaran . .

c. Memberi bimbingan teknis sekaligus membuat rencana pembelajaran dengan membuat alat peraga IPA.

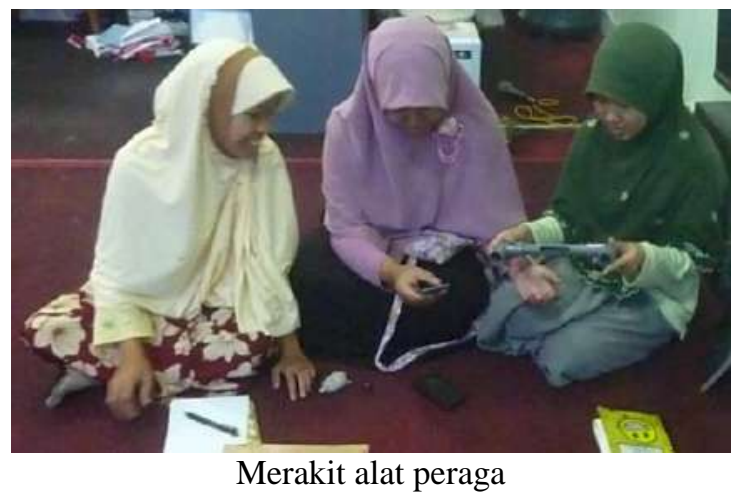

Secara garis besar hasil kegiatan yang telah dicapai dalam pengabdian Kepada masyarakat ini adalah sebagai berikut:

1. Materi pelatihan mempunyai arti penting dalam meningkatkan kualitas pengajaran. 
2. Materi pelatihan lebih mudah untuk dapat dipahami, serta mendapat respon dari peserta, yang ditandai dengan adanya pertanyaan yang muncul.

3. Berdasarkan sikap dan pertanyaan yang diajukan dapat diketahui bahwa materi pengabdian dapat dipahami dan sangat membantu dalam peningkatan kualitas pembelajaran.

4. Dari hasil Pengabdian ini diharapkan nantinya akan ada tindak lanjut berupa pelatihan dan bimbingan untuk materi belajar yang lain.

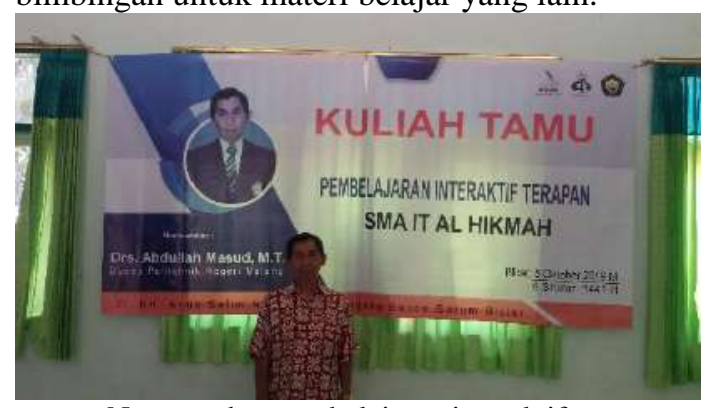

Nara sumber pembelajaran interaktif

\subsection{Faktor Pendukung}

Faktor yang mendukung terlaksananya kegiatan ini

a. Adanya dukungan yang positif dari pihak sekolah khususnya Kepala Sekolah SMP IT AL HIKMAH

b. Antuasisme dari guru-guru SMP IT AL HIKMAH selama mengikuti pelatihan .

\subsection{Faktor Penghambat}

Faktor yang menghambat kegiatan ini, antara lain

a. Menentukan jadwal kegiatan PKM yang tidak mengganggu kegiatan prosses belajar mengajar.

b. Sikap pesimis guru untuk meningkatkan kualitas proses belajar mengajar jika tidak didukung oleh dana yang memadai.

c. Terbatasnya fasilitas sarana prasarana untuk kebutuhan proses pembelajaran

\subsection{Rancangan Evaluasi}

Rancangan evaluasi dilakukan, antara lain ;

a. Evaluasi kegiatan dilakukan selama proses dan akhir pelatihan,

b. aspek pencapaian tujuan pelatihan dan juga penyelenggaraan pelatihan.

c. Evaluasi proses dan hasil dilakukan dengan angket tanya jawab, dan observasi.

d. evaluasi aspek penyelenggaraan pelatihan dilakukan dengan pemberian angket.

e. Indikator keberhasilan dalam pelaksanaan pelatihan ada 2 metode yang ditempuh, yaitu:

- Evaluasi selama proses pelatihan, dan

- evaluasi pasca pelatihan.

\subsection{Evaluasi selama proses pelatihan}

Evaluasi saat pelaksanaan pelatihan meliputi, keterlibatan dan kemampuan peserta setiap tahap pelatihan. Pada Tahap akhir, peserta diharapkan dapat melakukan kegiatan teknis pembuatan alat peraga IPA

a. mengidentifikasi,dan merumuskan pokok bahasan,

b. menyusun Daftar isi (outline), c. mengumpulkan bahan-bahan pustaka meng organisasikan, dan mengonsep tulisan,

d. memindah tulisan, gambar, video youtube kedalam powerpoint..

Indikator keberhasilan pelatihan ini adalah apabila:

a. Lebih dari $80 \%$ Guru-guru memahami hasil kegiatan pelatihan

b. Lebih dari $75 \%$ Guru-guru mampu mempratekkan

c. Lebih dari $50 \%$ Guru-guru bersedia mensosialisasikan kemampuan/ketrampilan.

\subsection{Evaluasi Pasca Pelatihan}

Keberhasilan kegiatan pengabdian masyarakat ini akan dievaluasi berdasarkan taraf penyelesaian materi pelatihan, dan Tim Pengabdian akan melakukan evaluasi dengan mengamati dan memeriksa alat peraga (alat peraga IPA) yang dibuat Guru-guru saat pelatihan. Instrumen kriteria penilaian tingkat kebermanfaatan kegiatan pelatihan ini.

\section{KESIMPULAN DAN SARAN}

\subsection{Kesimpulan}

Melalui penggunaan alat peraga dalam pembelajaran IPA, bahan ajar IPA dapat disampaikan guru dengan mudah dapat diterima siswa sehingga dapat memberikan perubahan yang lebih baik pada perkembangannya, dan kesadaran guru pentingnya memanfaatkan alat peraga IPA sebagai media untuk belajar.

\subsection{Saran}

- Para guru SMP IT AL HIKMAH perlu menguasai fasilitas T.I. membuat dan penggunaan alat peraga IPA yang bisa meningkatkan pelayanan siswa dalam hal proses belajar-mengajar IPA di kelas;

- SMP IT AL HIKMAH hendaknya memfasilitasi pembelajaran dengan menggunakan alat peraga IPA untuk memudahkan siswa menyerap materi pelajaran yang diajarkan guru.

- Perlunya tindak lanjut kegiatan ini, mengingat alat peraga IPA dapat dibuat oleh siswa sendiri dengan memanfaatkan bahan bekas yang ada disekitar kita.

\section{DAFTAR PUSTAKA}

[1]. ANDI.J.D. Latuheru. 2006. Media Pembelajaran dalam Proses Belajar-Mengajar Masa Kini. Jakarta: Departemen Pendidikan dan kebudayaan.

[2]. Depdiknas. (2002). Pembelajaran dan Pengajaran Kontekstual. Jakarta : Depdiknas

[3]. Edi Istiyono dan Insih Wilujeng. 2003. Pelatihan Penyusunan Perangkat Percobaan IPA (Fisika) Guna Menyongsong Pelaksanaan KBK Untuk Guru-guru SD Cokrokusuman Yogyakarta (Laporan PPM). Yogyakarta: FMIPA Universitas Negeri Yogyakarta.

[4]. Ibrahim, M. \& Nur, M. (2000). Pembelajaran Berdasarkan Masalah : Surabaya : UnesaUniversity Press 
[5]. Suyanto, M. 2004. Multimedia Alat untuk Meningkatkan Keunggulan Bersaing. Yogyakarta:

[6]. Thiagarajan, Savasailam, Semmel, DS, Semmel, Melvyn I. 1974. Instructional Development for Training Teacher of Exceptional Children. Minnepolis: Indiana University

[7]. Wasis, dkk. (2002). Beberapa Model Pengajaran dan Strategi Pembelajaran IPA Fisika. Jakarta : Depdiknas. 